Top-down approaches for sharing GHG emission reductions : uncertainties and sensitivities in the 27 European Union Member States

Saikku, Laura

Elsevier

2008

http://hdl.handle.net/10138/14548

http://dx.doi.org/10.1016/j.envsci.2008.07.002

Downloaded from Helda, University of Helsinki institutional repository.

This is an electronic reprint of the original article.

This reprint may differ from the original in pagination and typographic detail.

Please cite the original version. 


\title{
Top-down approaches for sharing GHG emission reductions: uncertainties and sensitivities in the 27 European Union Member States
}

Environmental Science \& Policy 11 (2008) 723-734

Laura Saikku ${ }^{a,}{ }^{,}$, Sampo Soimakallio ${ }^{b}$

${ }^{a}$ University of Helsinki, Department of Biological and Environmental Sciences. P.O. Box 27. 00014 University of Helsinki. Finland.

${ }^{\mathrm{b}}$ VTT Technical Research Centre of Finland, P.O. BOX 1000, FIN-02044 VTT, Finland

*Corresponding author. Tel. + 3589191 57769. E-mail address: laura.saikku@ helsinki.fi

\begin{abstract}
To reduce GHG emissions, the EU27 countries committed themselves in 2007 to reduce emissions from 1990 levels by $20 \%$ by 2020 . In January 2008, the EU commission gave the first country-specific proposals to reduce emissions in sectors outside the EU emission trading system (non-ETS). In this study, we looked at several ways of sharing emission reductions in the non-ETS sector. We considered population and economic growth as significant drivers of the development of emissions. In particular, we analyzed development in GHG intensity of economies. Reduction requirements vary greatly among countries depending on the principle of effort sharing. The results of our calculations can be perceived as examples of how effort sharing between the EU Member States could look like when certain assumptions are made. Generally they illustrate the sensitivity of the results to data used, assumptions made, and method applied. The main strength of simple top-down approaches is transparency. A major weakness is a very limited ability to consider national circumstances. Political negotiations are ultimately crucial; an analysis like this provides material for negotiations and makes a contribution to solving the effort-sharing problem. As future development is partly unpredictable, implementation of some kind of subsequent adjustment could be considered during the process.
\end{abstract}

Keywords: GHG emissions, effort sharing, EU27, GHG intensity of economy, top-down approach 


\section{Introduction}

Human-inflicted greenhouse gas emissions affect the global temperature. The global mean temperature is expected to increase significantly and there is a growing risk of extreme climatic events (IPCC 2007). In 1996, the European Commission recommended that the rise in global average temperature should be limited to $2{ }^{\circ} \mathrm{C}$ above the pre-industrial level. The European Union, accounting for approximately 14\% of global GHG emissions (European Commission 2005), is in the forefront of combating climate change. In March 2007, the EU Prime $M$ inisters agreed on a post-Kyoto target, a commitment of a $20 \%$ reduction of GHG emissions by 2020 from 1990 levels. On the condition that other countries also commit to reductions, they agreed that the EU countries should reduce GHG emissions by $30 \%$ for the same period.

To arrive at $20 \%$ emission cuts by 2020 is, however, challenging. To achieve the particular target of reducing $\mathrm{CO}_{2}$ emissions alone is a demanding task, as this would mean around a two-fold improvement in the decarbonisation and dematerialisation rates occurred in the EU27 during 1993-2004 (Saikku et al. 2008). In that period, affluence and population grew strongly, more than offsetting the modest efficiency gains. The rates of dematerialisation and decarbonisation varied between countries, with faster development in the 12 new Member States than in the EU15. Consideration of reducing non- $\mathrm{CO}_{2}$ greenhouse gas emissions provides some relief to the challenge as there are many cost-effective options to reduce these emissions (Delhotal et al. 2006). Consideration of ecosystem biomass as a carbon sink, as well as implementation of emission reductions in developing countries through the Clean Development M echanism (CDM) would have considerable significance for the EU, but these are dependent on the development of the international climate policy.

The European Commission proposed legally binding Post-Kyoto targets for its current 27 Member States on 23 January 2008 (Commission 2008). Emissions would be reduced separately in the emission trading sector (including mainly energy and industrial GHG emissions), and sectors not included in emission trading (non-ETS), such as residential, agriculture, transportation and waste management. The proposed reduction in the Emission trading sector was 21\% and in the non-ETS sector 10\% from the 2005 level (Commission 2008). The emission trading sector will be administered at the EU level whereas the other sectors will be given an overall national target. The proposal in the non-ETS sector divides emission reduction efforts between M ember States based on simple GDP per capita criteria. According to the Commission, countries with low GDP/capita and high GDP growth expectations should be allowed to increase their emissions.

Effort sharing approaches can be studied from many different perspectives. Besides topdown methods, an approach may be based on more sophisticated and data-oriented bottom-up methods. For EU Member States, the internal burden sharing of the Kyoto Protocol was previously negotiated on the basis of Triptych method (Blok et al. 1997). Triptych is a relatively simple sectoral approach for sharing national emission allowances, serving to improve understanding about differences in national circumstances relevant to burden differentiation. The approach enhances population size and population growth, economic structure, emission intensity of economy as $\mathrm{CO}_{2} / \mathrm{GDP}$, affluence as GDP/capita, standard of living as $\mathrm{CO}_{2} /$ capita, energy efficiency as $\mathrm{CO}_{2} /$ Energy, fuel mix and climate as 
heating degree days (Phylipsen et al 1998). Triptych has been later expanded as a global application to set post-Kyoto targets. The sensitivity and suitability of the extended Triptych approach developed by Ecofys (Phylipsen et al. 2004) to set emission quotas was tested and analysed by Soimakallio et al. (2006). In addition to the Triptych approach, other options for differentiating GHG mitigation commitments internationally and in the EU, particularly for the post-Kyoto period, were summarised, among others, by Sijm et al. (2007).

Any effort sharing principle should be politically acceptable with respect to fairness principles and operational requirements (Torvanger and Ringius 2001). The key issue with an effort-sharing method is the dilemma between its transparency, on the one hand, and its ability to take into account national circumstances, on the other hand (Soimakallio et al. 2006). The data used for calculating the targets for the parties should be robust, generally acceptable, and transparent so as to be open to critical analysis. The latter requirement can easily conflict with effort-sharing methods based on sophisticated model calculations, which are typically required for responding to certain scopes of fairness. The strengths of simple top-down methods are relatively good availability and a limited amount of required data, as well as transparency of the method. However, the restricted ability to consider national circumstances and factors explaining top-down figures can be seen as a major weakness.

This paper presents a few top-down approaches to sharing the effort to reduce greenhouse gas emissions outside the EU's emission trading system within the EU countries by 2020 . The top-down approaches studied are based on the economy's greenhouse gas intensity by taking into account the forecasted economic and population growth. In addition, we consider and evaluate the EU Commission preliminary proposal for effort sharing from the viewpoint of our results. Finally, we discuss different top-down approaches, sensitivities in the results and uncertainties related to studies based on forecasts.

\section{Data sources and methods}

\subsection{Scenarios in this study}

Top-down macro figures are used in the approaches studied to set the emission reduction targets for the Member States. The approach takes into account the current level of greenhouse gas emissions (Appendix 1.) and the forecasted growth of population and the economy in the different Member States, and simply sets the targets for greenhouse gas intensity of economy in terms of GHG/GDP for the non-ETS sector by applying various rules.

Four different effort sharing scenarios were calculated for non-ETS emission reduction. The reduction is assumed to start in 2008. The total reduction in the non-ETS sector is determined through reductions in the ETS sector. ETS emissions in countries are reduced by $20 \%$ from 2005 verified emissions. The reduction in the ETS sector is determined by the grandfathering principle, where each country reduces their emissions by the same share. Non-ETS sector as a whole reduces 8\% from 2005 level. Emission data for year 2005 is used as a starting point for reduction, assuming that 2005 emissions are equal to 2008, as 2005 is the latest year of available data. The GDP forecast for 2008 is used. All scenarios refer to non-ETS only. 
Scenario 1: The annual rate of change in GHG/GDP is the same in all M ember States during 13 years, 2008-2020.

Scenario 2: GHG/GDP becomes equal in all countries in 2020.

Scenario 3: National rates of GHG/GDP are the same as they were in 1993-2005. In order to reach a reduction of $20 \%$ by 2020 , an additional reduction is required. This additional annual reduction is set constant over time and the same for all countries in percentage terms.

Scenario 4: GHG per capita becomes equal in all countries in 2020.

\subsection{Data}

The historical data for greenhouse gas emissions and GDP, as well as forecasts for population growth (baseline variant by 2020) in the different Member States, were derived from the Eurostat database (2008). Population growth is predicted to influence development to some extent, around 1\% per year in Ireland and some small countries like Cyprus (Appendix 2). Population acts as a downward force for e.g. Bulgaria, Latvia, Lithuania and Estonia.

Forecasts of economic development were carried out according to a model described in more detail in Saikku et al. (2008). In the model, real GDP growth rates for 2007-2008 as reported by Eurostat $(2008)$ were used in the forecasts. For projections of the development of total GDP after 2008, countries were divided into four groups based on the level of their affluence (GDP/capita) in 2006. The GDP's of the countries in the richest group are set to grow at a rate of $2 \%$ per year. The other three groups of countries converge to the average affluence level of the richest group at differing time-spans, depending on their initial level of affluence.

We used estimates for the non-ETS sectors' GDP in our calculation. The approximated GDP share of the Emission Trading Scheme (ETS) sectors is roughly based on Eurostat (2008) GDP data, on GDP of the energy industries, the manufacturing industries and construction, and industrial processes. The non-ETS sector GDP is a complement of the ETS sector GDP.

Non-ETS GDP growth in years 2008-2020 is expected to be considerable, more than $5 \%$ per year, for a few countries: Romania, Poland, Bulgaria, Hungary and Slovakia (Appendix 2). GDP growth is projected to be most modest, around $2 \%$ per year, in some other western countries, for instance Germany and France.

We also compared required GHG intensities in our scenarios to recent historical development. Historical development in GHG/GDP during 1993-2005 was calculated for total GDP. Non-ETS GHG estimated for 1993 is based on Eurostat emissions for the energy industries, and manufacturing and industrial processes. GDP (ppp-corrected) for 1993 from Penn World Table (Heston et al. 2007). 


\subsection{Sensitivity analysis}

We conducted the following test runs for all scenarios to analyse certain sensitivities involved in the results. In comparison to the base case presented above:

Test run 1: The base year for emissions is changed to 2004.

Test run 2: Emissions in the ETS sector are reduced by $20 \%$ from the second national allocation plans for 2008-2012, approved by the European Commission (European Commission 2007).

Test run 3: Emissions in the ETS sector are reduced $0 \%$ from the verified emissions in 2005.

Test run 4: GDP forecasts presented in Mantzos et al. (2003) and POLES model (Russ et al. 2007). ${ }^{1}$

Test run 5: The base year for GDP is changed to 2004 and 2005, in addition, overall GDP is used instead of non-ETS GDP.

Test run 6: Population forecasts are calculated according to Eurostat High and Low variants.

\section{Results}

The effort sharing approaches studied varied relatively significantly in terms of greenhouse gas targets for 2020 in the non-ETS sector for EU M ember States (Fig. 1, see detailed results for all countries in four scenarios in Appendix 3). Countries' reduction targets are determined by their level of GHG emission in the starting year (2008), their current GDP and population level and growth expectations. Also historical development in GHG/GDP has an impact in one scenario.

In scenario 1, all countries need to improve their GHG intensity of economy at the same rate. The emission reduction target depends on the growth rate of GDP. Those countries with highest estimated GDP growth are allowed to increase their emissions. The other way around, for example Germany has lowest expected GDP growth and tightest emission reduction target.

\footnotetext{
${ }^{1}$ The two reference forecasts of POLES and M antzos et al. are more sophisticated approaches on GDP growth and are based on detailed system models. The growth expectations for several Eastern European countries are much more modest (max 3\%/ year for any EU country) compared to Saikku et al. In fact, some countries' GDP is expected even to decrease (Latvia in POLES and M antzos et al., in addition, Bulgaria, Czech, Estonia, Hungary, Romania, Slovakia and Slovenia in M antzos et al.). The forecast of POLES is PPP corrected, similarly to Saikku et al. (2008) and the expected growth fall very close to each other for a few Western European countries (e.g. Denmark, Germany, Netherlands, Luxembourg, Finland, Belgium). Also, the growth expectations for these countries are more modest when comparing to Mantzos et al.
} 
Scenario 2 assumes equal emission per GDP for all countries in 2020. The emission reduction target depends on the level of GHG/GDP in the starting year in relation to estimated GDP growth. Those countries with low GHG/GDP level in the starting year (2008) together with relatively high increase in expected GDP growth can emit the most (like Malta and Latvia). Sweden, in particular, is allowed to grow its emissions because the level of GHG/GDP in base year is low although its GDP growth is below the EU average.

Scenario 3 is based on historical rates of GHG/GDP. Emission reduction targets depend on historical rates of GHG/GDP multiplied with expected GDP growth. Those countries whose historical rate in GHG/GDP has been decreasing intensively combined with moderate GDP growth expectations get the toughest targets (like Ireland, Finland, United Kingdom, Denmark and Sweden). Although expected GDP growth in Latvia exceeds the EU average the country should reduce emissions significantly in scenario 3 due to a remarkable decrease in historical GHG/GDP.

Scenario 4 assumes equal emissions per capita for all countries in 2020. Emission targets depend on the factor determined by GHG/capita in the starting year in relation to population growth. Those countries with a low GHG/capita level in the starting year (2008) and/or high estimated increase in population growth are allowed to emit the most, like Malta, Latvia, Romania and Bulgaria.

Variation in emission targets between scenarios for particular countries was considerable for some of the Member States but more moderate for others (Fig. 1). The variation between scenarios was moderate when the determining factors in a particular country were close to the EU average in all scenarios. However, as the determining factors, e.g. GDP growth in scenario 1 or emissions per capita in relation to population growth in scenario 4, vary between scenarios, there is no clear answer why the deviation is more considerable for some countries than the others. The variation in terms of percentage points was large for Latvia, Slovakia, Romania and Luxembourg. For Cyprus, Netherlands and Estonia, and also, Slovenia, Germany and France, variation was small. The reduction targets proposed by the Commission (Appendix 3 ) fall in the range of the results in our study for all countries, except Slovenia. 


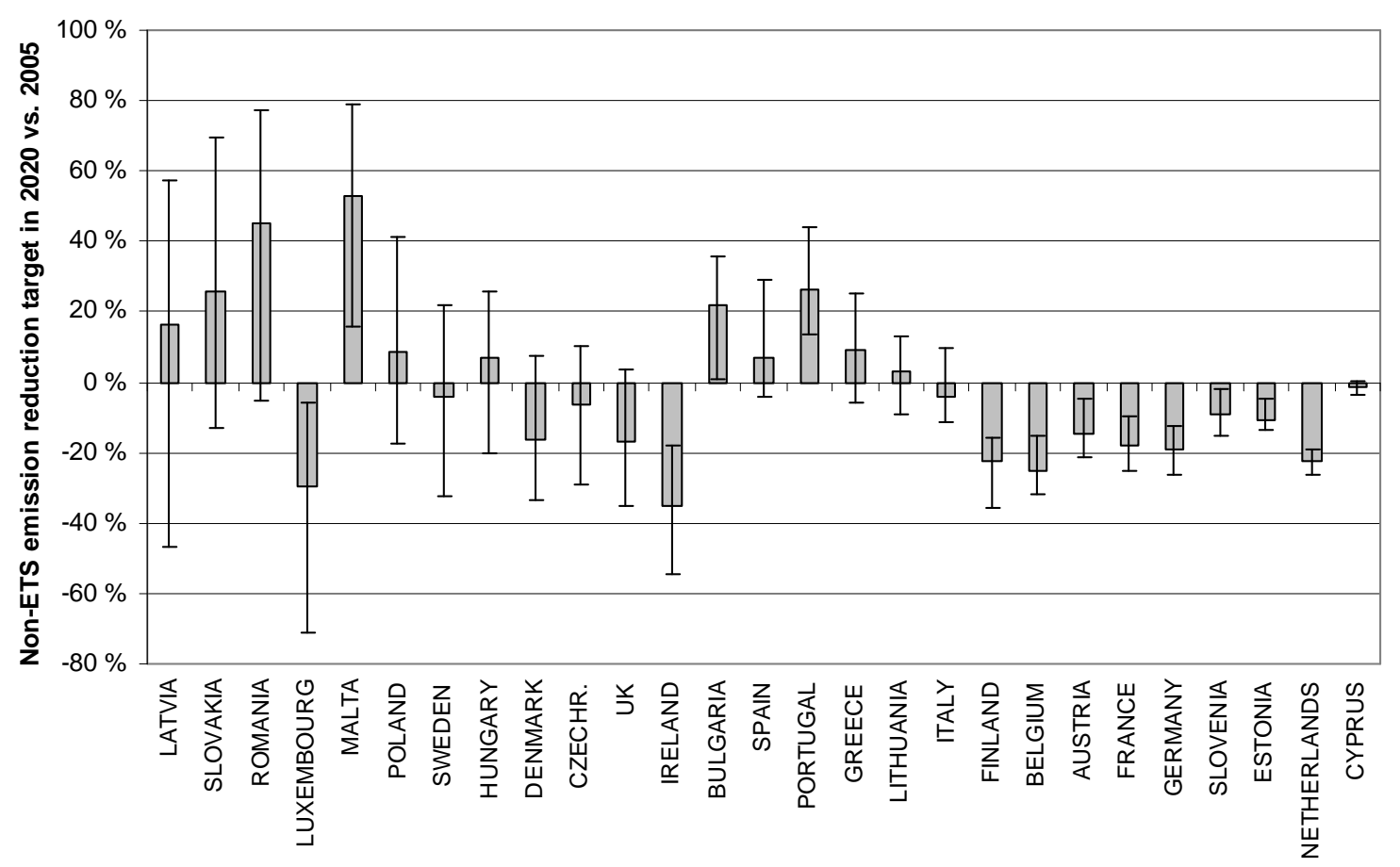

Figure 1. Average change in non-ETS emissions in different scenarios for 2020 in comparison with 2005. Error bars represent the variation range ( $\mathrm{min}$ and $\mathrm{max}$ ) in terms of percentage points. Countries furthest left have largest variation between scenarios.

There is variation in the stringency of targets between scenarios for each country (table 1). For example, scenario 1 (equal non-ETS reduction in GHG/GDP), results in toughest targets for a few countries that are below the EU average both in 2005 and 2020, in terms of absolute GHG intensity of economy. Between different scenarios, Equal non-ETS GHG per GDP favours wealthy western countries like Denmark and France, but also Latvia. However, when other GDP forecasts are used, the GHG/capita option becomes more favourable for Latvia.

Scenario 3, historical rates of GHG/GDP, yields tougher targets compared to other scenarios for a few Western Europe countries like Ireland and some Eastern European countries, like Latvia and Lithuania. In Eastern Europe, a structural change occurred during 1993-2005 and more of the decrease in non-ETS GHG/GDP can be attributed to strong GDP growth than falling emissions. Also, in these countries, GHG/GDP in 1993 was at a high absolute level. In Ireland the absolute level was much above the EU average in the beginning of the historical period in comparison. The variation in terms of reduction targets is widest in scenario 4; however, it is the most extreme only for a few countries. Looking at all countries' average requirements in different scenarios (fig. 1), would result in $-8 \%$ total change from 2005 level, thus filling the actual target in our scenarios. Combination of all countries "easiest" targets, would result in $+7 \%$ change in emissions compared to 2005 level, and toughest targets, in $22 \%$ change, respectively. 
Table 1. Toughest and easiest scenarios for countries.

\begin{tabular}{|l|l|l|}
\hline & Toughest & "Easiest" \\
\hline Scenario 1 & Austria, Italy, Portugal, Spain, Malta & $\begin{array}{l}\text { Bulgaria, Estonia, Ireland, Poland, } \\
\text { Romania, Lithuania }\end{array}$ \\
\hline Scenario 2 & $\begin{array}{l}\text { Bulgaria, Czech R., Estonia, Hungary, } \\
\text { Poland, Slovakia, Romania }\end{array}$ & $\begin{array}{l}\text { Denmark, France, Latvia, Netherlands, } \\
\text { Sweden, UK }\end{array}$ \\
\hline Scenario 3 & $\begin{array}{l}\text { Cyprus, Denmark, Finland, France, } \\
\text { Germany, Ireland, Latvia, Lithuania, } \\
\text { Slovenia, Sweden, UK }\end{array}$ & $\begin{array}{l}\text { Austria, Belgium, Czech R., Greece, } \\
\text { Hungary, Italy, Luxembourg, Portugal, } \\
\text { Slovakia, Spain }\end{array}$ \\
\hline Scenario 4 & Belgium, Greece, Luxembourg, & $\begin{array}{l}\text { Cyprus, Finland, Germany, Malta, } \\
\text { Slovenia }\end{array}$ \\
& Netherlands & \\
\hline
\end{tabular}

When looking at the requirements for improving the greenhouse gas intensity of economy in the non-ETS sector, the relatively fastest improvement is required especially in Luxembourg, Ireland and in some Eastern European countries, Like Poland and Romania (table 2.). However, according to our scenarios, Ireland is the only country that comes close to maintaining the historical rate, on average. Latvia faces great reduction requirements, if emissions are reduced based on reductions in GHG intensity in the past (scenario 3). Nevertheless, Latvia would be allowed on average less improvement in annual GHG intensity than during 1993-2005. Slovakia, Romania and Poland would face toughest GHG intensity reduction requirements in scenario 2, equal GHG per GDP. For Sweden, UK, Finland and Denmark, the required effort is less than double the historical rate. For most countries, the EU-proposal rates are close to the average rates in our scenarios. 
Table 2. Average annual non-ETS GHG/GDP intensity change requirement during 2008-2020 (13 years) in four scenarios, according to the EU proposal and historical change during 19932005.

\begin{tabular}{|c|c|c|c|c|c|c|c|}
\hline Member State & $\begin{array}{l}1993- \\
2005\end{array}$ & $\begin{array}{l}\text { EU } \\
\text { proposal }\end{array}$ & SCE1 & SCE2 & SCE3 & SCE4 & $\begin{array}{l}\text { AVERAGE } \\
\text { in SCE1-4 }\end{array}$ \\
\hline Austria & $0,6 \%$ & $-3,5 \%$ & $-3,7 \%$ & $-2,8 \%$ & $-2,3 \%$ & $-3,6 \%$ & $-3,1 \%$ \\
\hline Belgium & $-0,2 \%$ & $-3,3 \%$ & $-3,7 \%$ & $-4,7 \%$ & $-3,1 \%$ & $-4,7 \%$ & $-4,1 \%$ \\
\hline Bulgaria & $-1,7 \%$ & $-5,0 \%$ & $-3,7 \%$ & $-5,9 \%$ & $-4,6 \%$ & $-4,0 \%$ & $-4,5 \%$ \\
\hline Cyprus & $-1,0 \%$ & $-4,3 \%$ & $-3,7 \%$ & $-3,7 \%$ & $-3,9 \%$ & $-3,6 \%$ & $-3,7 \%$ \\
\hline Czech Republic & $-0,5 \%$ & $-3,8 \%$ & $-3,7 \%$ & $-6,6 \%$ & $-3,4 \%$ & $-5,0 \%$ & $-4,7 \%$ \\
\hline Denmark & $-2,1 \%$ & $-3,9 \%$ & $-3,7 \%$ & $-1,4 \%$ & $-4,9 \%$ & $-3,3 \%$ & $-3,3 \%$ \\
\hline Estonia & $-1,4 \%$ & $-2,8 \%$ & $-3,7 \%$ & $-4,5 \%$ & $-4,3 \%$ & $-4,4 \%$ & $-4,2 \%$ \\
\hline Finland & $-2,4 \%$ & $-3,6 \%$ & $-3,7 \%$ & $-3,7 \%$ & $-5,3 \%$ & $-3,3 \%$ & $-4,0 \%$ \\
\hline France & $-1,1 \%$ & $-3,2 \%$ & $-3,7 \%$ & $-2,6 \%$ & $-4,0 \%$ & $-3,0 \%$ & $-3,3 \%$ \\
\hline Germany & $-1,2 \%$ & $-3,2 \%$ & $-3,7 \%$ & $-3,1 \%$ & $-4,1 \%$ & $-2,8 \%$ & $-3,4 \%$ \\
\hline Greece & $0,1 \%$ & $-5,1 \%$ & $-3,7 \%$ & $-4,0 \%$ & $-2,8 \%$ & $-4,8 \%$ & $-3,8 \%$ \\
\hline Hungary & $-0,6 \%$ & $-4,9 \%$ & $-3,7 \%$ & $-6,8 \%$ & $-3,5 \%$ & $-5,2 \%$ & $-4,8 \%$ \\
\hline Ireland & $-5,1 \%$ & $-4,2 \%$ & $-3,7 \%$ & $-4,3 \%$ & $-8,0 \%$ & $-6,5 \%$ & $-5,6 \%$ \\
\hline Italy & $0,7 \%$ & $-4,2 \%$ & $-3,7 \%$ & $-3,4 \%$ & $-2,1 \%$ & $-3,4 \%$ & $-3,2 \%$ \\
\hline Latvia & $-5,9 \%$ & $-3,3 \%$ & $-3,7 \%$ & $-0,8 \%$ & $-8,7 \%$ & $-1,3 \%$ & $-3,6 \%$ \\
\hline Lithuania & $-2,4 \%$ & $-3,9 \%$ & $-3,7 \%$ & $-4,8 \%$ & $-5,3 \%$ & $-3,8 \%$ & $-4,4 \%$ \\
\hline Luxembourg & $0,2 \%$ & $-4,2 \%$ & $-3,7 \%$ & $-4,2 \%$ & $-2,6 \%$ & $-11,1 \%$ & $-5,4 \%$ \\
\hline Malta & $0,6 \%$ & $-4,8 \%$ & $-3,7 \%$ & $-0,6 \%$ & $-2,3 \%$ & $-0,4 \%$ & $-1,8 \%$ \\
\hline Netherlands & $-1,0 \%$ & $-3,4 \%$ & $-3,7 \%$ & $-3,4 \%$ & $-3,8 \%$ & $-4,1 \%$ & $-3,8 \%$ \\
\hline Poland & $-3,0 \%$ & $-5,7 \%$ & $-3,7 \%$ & $-7,6 \%$ & $-5,9 \%$ & $-5,8 \%$ & $-5,8 \%$ \\
\hline Portugal & $1,0 \%$ & $-4,9 \%$ & $-3,7 \%$ & $-3,0 \%$ & $-1,9 \%$ & $-3,0 \%$ & $-2,9 \%$ \\
\hline Romania & $-1,1 \%$ & $-7,1 \%$ & $-3,7 \%$ & $-8,2 \%$ & $-4,0 \%$ & $-5,5 \%$ & $-5,4 \%$ \\
\hline Slovakia & $1,8 \%$ & $-4,5 \%$ & $-3,7 \%$ & $-6,1 \%$ & $-1,1 \%$ & $-3,3 \%$ & $-3,5 \%$ \\
\hline Slovenia & $-1,2 \%$ & $-2,8 \%$ & $-3,7 \%$ & $-3,6 \%$ & $-4,1 \%$ & $-3,0 \%$ & $-3,6 \%$ \\
\hline Spain & $1,4 \%$ & $-4,5 \%$ & $-3,7 \%$ & $-3,3 \%$ & $-1,5 \%$ & $-3,4 \%$ & $-3,0 \%$ \\
\hline Sweden & $-2,1 \%$ & $-3,7 \%$ & $-3,7 \%$ & $-0,5 \%$ & $-5,0 \%$ & $-1,1 \%$ & $-2,6 \%$ \\
\hline United Kingdom & $-2,2 \%$ & $-3,5 \%$ & $-3,7 \%$ & $-1,6 \%$ & $-5,1 \%$ & $-3,1 \%$ & $-3,4 \%$ \\
\hline
\end{tabular}

Sensitivities in the results

Changing assumptions in the scenarios causes a great deal of variation in the reduction targets for countries (appendix 4). Changing the base year from 2005 to 2004 results in mainly minor differences for countries in scenarios 1 and 3 . There is no impact on targets for scenarios 2 and 4 as these scenarios use projections for 2020 as a basis for calculations (Fig. 2). Countries with lower emissions in the selected base year than their average level are given tougher targets since reductions start from a lower level. Changing the base year from 2005 to 2004 would result in tougher targets for Estonia and Poland, among others, and easier targets for, for example, Slovakia and Portugal.

When the base year for ETS reductions is changed from 2005 to the Kyoto allocations (20082012), non-ETS effort increases for all countries by one to two percentage points. In 2005 total emissions in the ETS sector were relatively equal to those annually allocated for the 2008-2012 period for most of the countries and at the EU27 level. 
Changing the EU's total non-ETS reductions naturally has a great influence on the reduction targets of countries (Fig 3.). If ETS sector emission reductions were smaller, all countries would get tougher non-ETS targets. When ETS reduces $0 \%$ instead of $-20 \%$, non-ETS sector emissions are allowed to be $85 \%$ of the base case non-ETS emissions in 2020 in all scenarios for all countries. However, in terms of additional reduction percentage, variation between countries and scenarios depends on the relation between actual reduction and the size of 2005 emissions. Difference to base case is larger the smaller the relative emission reduction (/bigger the increase) in base case.

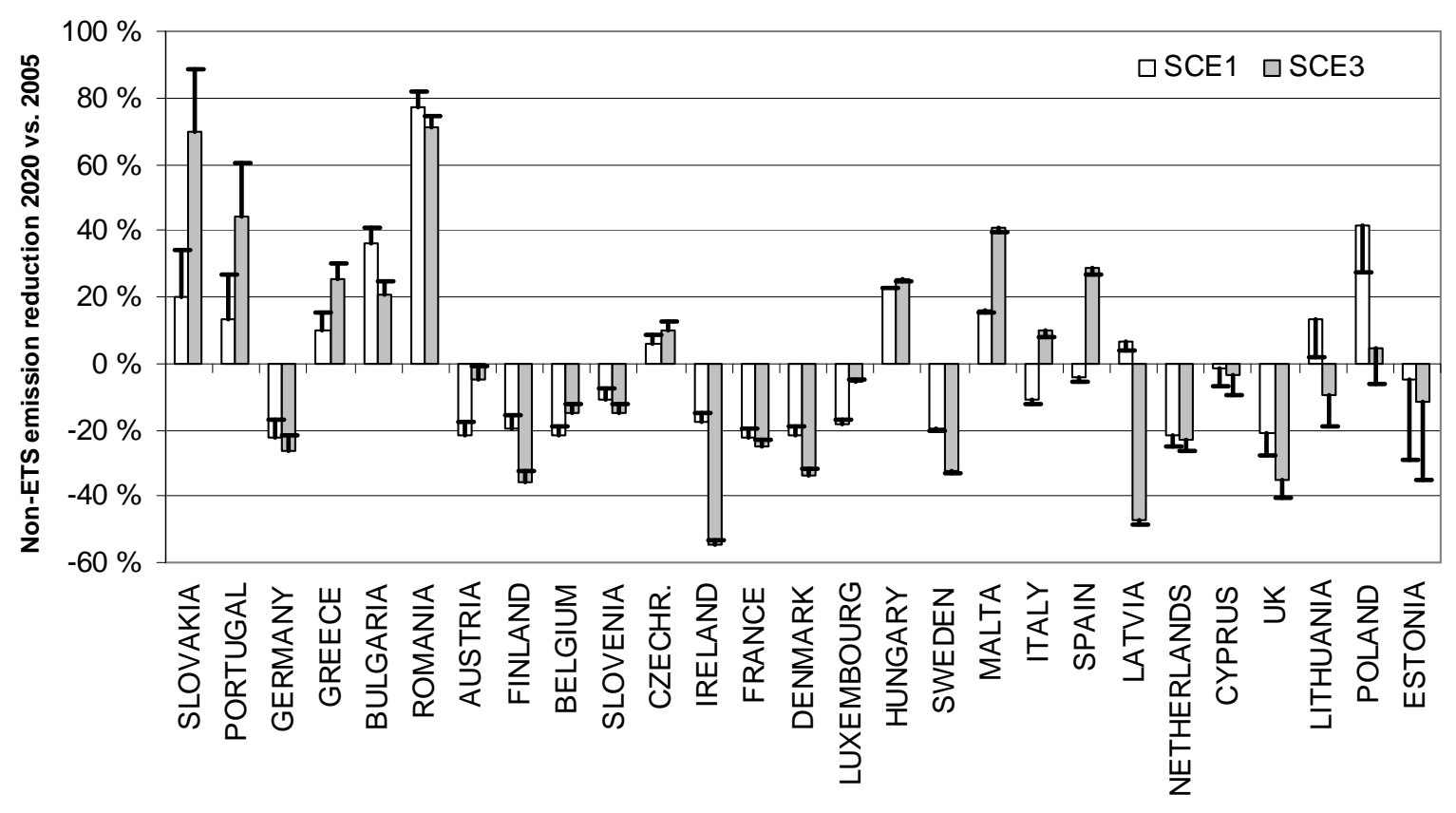

Figure 2. Test Run 1: Impact of changing the emission base year from 2005 to 2004 in scenarios 1 and 3. Error bars show the difference in emission reductions compared to the base case scenarios (columns). For scenarios 2 and 4, there was no impact. For countries furthest left, changing base year from 2005 to 2004 would yield easier targets and countries furthest right, tougher targets. 


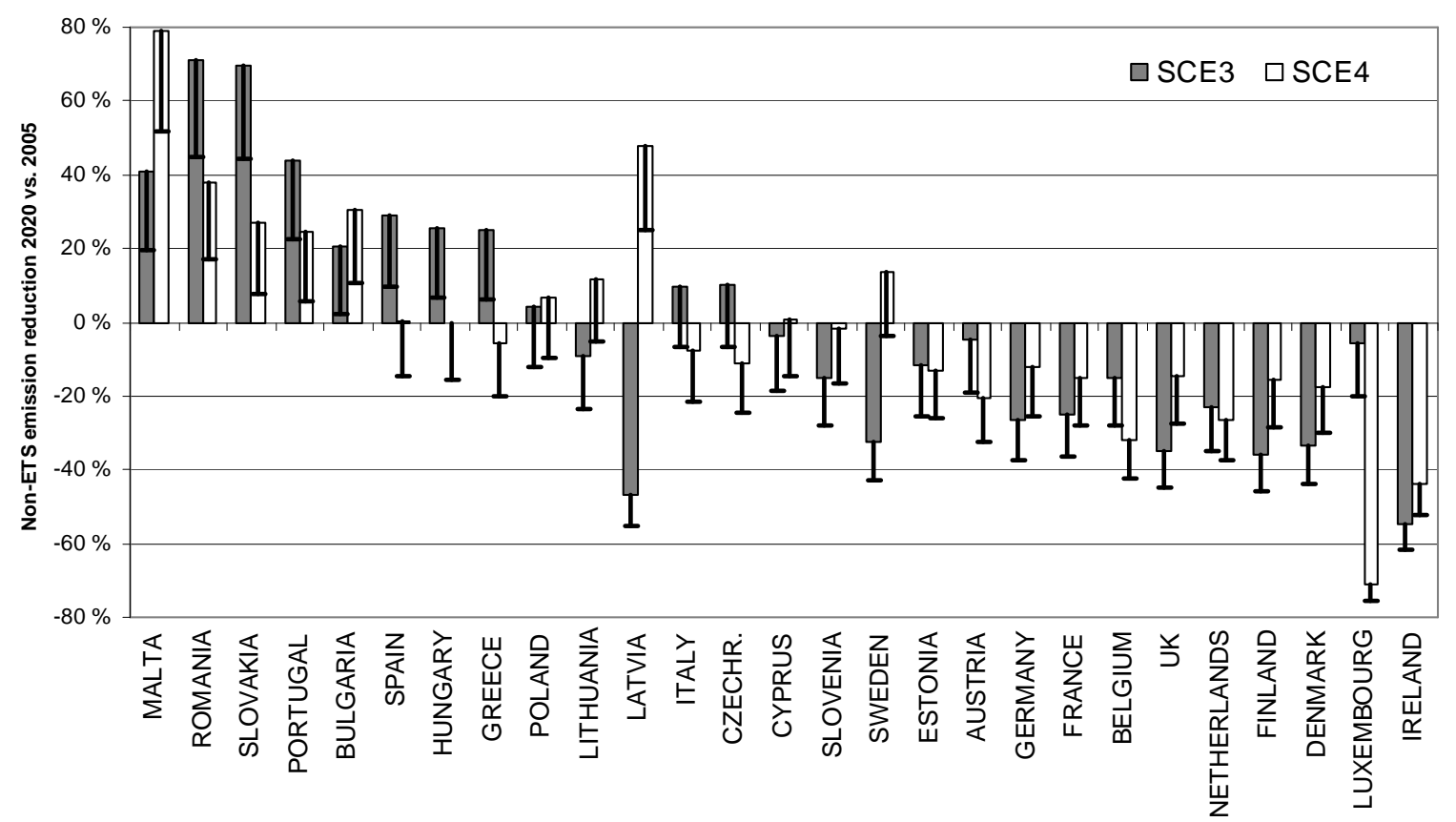

Figure 3. Test run 3. Impact of changing the requirement for ETS sector emission reductions from $-20 \%$ (columns) to $0 \%$ (error bars) compared to 2005 level in two example scenarios, 3 and 4 . The impact in terms of percentage points is largest on average in these two scenarios for countries furthest left in the figure.

Changing the GDP forecast has a great impact on the results in Scenarios 1, 2 and 3 (an example is SCE1 in Fig. 4). There is no impact on non-ETS reductions when the reductions are based on GHG per capita criteria (SCE4). The reductions with the POLES forecast (Russ et al. 2007) fall closer to the baseline in our study than that of Mantzos et al. (2003). Overall, the forecasts of POLES (Russ et al. 2007) and Mantzos et al. (2003) give tougher targets for eastern European countries compared to the base case scenarios with the forecast of Saikku et al. (2008), in which these countries are allowed to grow their emissions. The emission growth until 2020 is thus allowed by the growing economy, even though the GDP/GHG ratio would decrease. Much more moderate rates for these countries in reference forecasts suggest emission reductions between 2005 and 2020. For example, In Saikku et al., the GDP estimates for 2020 are at least twice as large as in the POLES model for Bulgaria, Latvia and Romania.

The impact of changing the base year for non-ETS GDP between 2004, 2005 or 2008 would be minor, as there is only a one percentage point difference for a few M ember States and no difference for the others in their share of the overall EU GDP for the different years. Even though the connection between the ETS and non-ETS sectors in terms of emissions and economic growth is somewhat unclear, using overall GDP instead of non-ETS GDP does have a minor impact on the results: there is only a one to two percentage point difference for a few MS and no difference for the others in their individual share of the overall EU GDP.

Changing population forecasts from Eurostat Baseline to Eurostat High or Low did not change the results in scenarios 1-3 and had only a slight impact on the reduction targets in scenario 4 (equal GHG per capita in 2020). The High forecast resulted in a 4 or more 
percentage points difference (lower non-ETS targets in this case) for three countries: Malta, Cyprus and Slovenia. With the Low forecast, Malta and Cyprus gained tougher (more that 4 percentage points) targets.

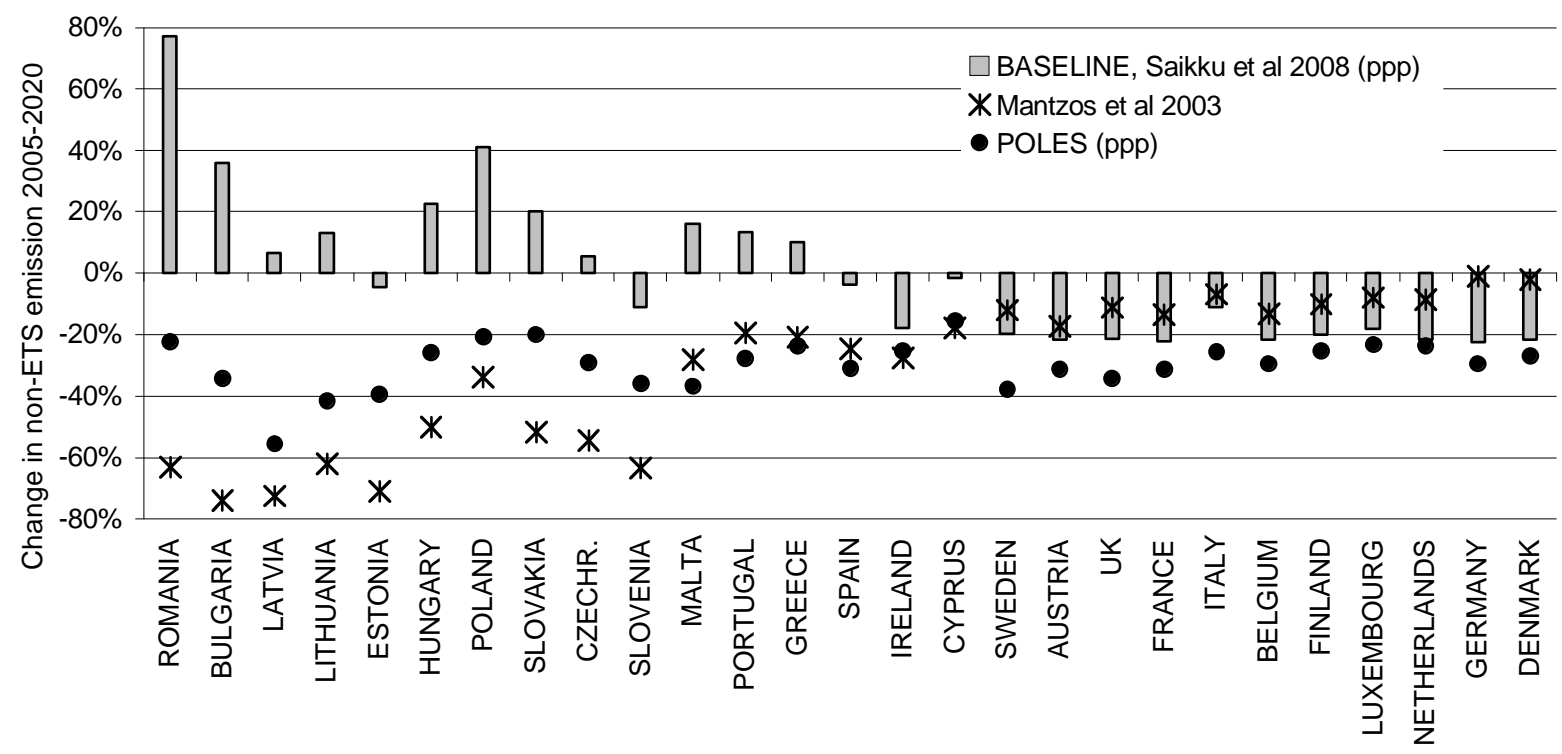

Figure 4. Test Run 4: Impact of changing GDP forecasts in Scenario 1 (baseline compared to reference forecasts). The reference forecasts have greatest variation compared to the baseline for countries furthest left. SCE1 is shown here as an example, the variation in SCE2 $\&$ SCE3 are for most countries the same order of magnitude; for scenario 4 (Equal GHG/capita), the GDP forecast is insignificant.

\section{Discussion}

To mitigate climate change, the EU has agreed upon a unilateral commitment to reduce GHG emissions by $20 \%$ from 1990 levels by 2020 . The European Commission has proposed separate targets for ETS and non-ETS sectors, being reductions of $21 \%$ and $10 \%$, respectively, compared to the emissions in 2005. The EU Commission has also proposed to share national reduction targets for the non-ETS sector by considering the ability to pay criteria (GDP/capita) and certain extra limitations. For the ETS sector no national quotas are given in the proposal (EC 2008).

We studied different ways of sharing the reduction targets among countries and assessed underlying assumptions of the calculations for the period until 2020. Estimates of non-ETS emissions for each EU country for 2020 were generated in alternative ways, which all met the unilateral reduction target as mentioned above for the EU as a whole. We considered unanimous annual reduction, historical development and convergence in GHG/GDP as a basis to share emission targets. In addition, GHG/capita convergence was applied. Different scenarios and changes in underlying assumptions caused great variation in emission reduction targets in this study. The emission reduction requirements for a given country varied depending on the criterion, confirming the findings of den Elzen et al. (2007).

The requirement for the total EU reduction of non-ETS emissions, and hence, the allocation of reduction between ETS and non-ETS, is of great importance. den Elzen et al. (2007) 
assessed that reducing non-ETS emissions is cost-effective and assumed around $31 \%$ reduction from 2005 levels within the non-ETS sector, which is more than the EU proposed . Ekholm et al. (2008) estimated a cost-optimal solution, where nearly equal requirements are set for ETS relative to non-ETS: 14\% less in 2020 than in 2005 at both sectors. Much uncertainty is associated to the reductions, as these studies and the EU proposal assume very different emission reduction between the ETS and the non-ETS sectors. Our sensitivity analysis showed that changing the allocation of emission reductions between the ETS and the non-ETS sector has significant influence on the national non-ETS reduction targets of countries, and thus on the reductions and related costs assigned for e.g. agricultural, residential and traffic sectors.

The assumptions behind the calculations are of great importance. The selection of the base year for data used in the calculations may have a significant influence on the results especially if the selected year is very exceptional for a certain country. Using the average values of a prolonged time period rather than one randomly selected year as a starting point for calculations would certainly be more representative.

In addition to statistical sensitivities, more importantly, the choice of GDP forecasts has a major impact on the results. In general, even though forecasts are important when determining emission targets, inequity is embedded in emission allowances when overestimation or underestimation of the future development of GDP occurs. The assumptions behind the Kyoto negotiations compared to the actual development as it took place were inaccurate for some of the Member States such as Finland (Soimakallio et al. 2005). In long-term commitments of emission reduction in nations, in order to mitigate the impact of the uncertainty in forecasts, effort sharing methods and monitoring mechanisms using some kind of adjustment rules can be considered preparing for unpredictable elements of change.

\subsection{Strengths and weaknesses of the effort sharing approach studied}

The major strength of simple top-down effort sharing methods in general is the transparency and limited amount of data required. In addition, statistics for generally known macroindicators are relatively well-available for different countries. However, at the same time such methods are very limited to take national circumstances explaining the background of macro-figures into account.

GHG emissions, GDP and population were the only statistical data required in the studied approaches in this paper. In addition, we considered forecasts of population and economic growth that can be seen as substantial drivers for the development of emissions. However, also population dynamics, incomes, as well as productive structures and energy intensities of the economy, significantly influence the volume of greenhouse gas emissions, and should be accounted for when allocating emission quotas (M artinez-Zarzoso et al. 2007).

According to Meyerson (1998) population issues were not considered in the formulation of the Kyoto protocol because of the complexity of population interactions as well as political issues. York (2007) explored fourteen European nations, finding that population size and age 
structure have clear effects on energy consumption. Also, economic development and urbanization contribute substantially to changes in energy consumption. Martinez-Zarzoso et al. (2007) found that especially for old EU Member States, the impact of population growth on $\mathrm{CO}_{2}$ emissions is less than proportional. For New EU countries, however, emissions grow relatively more as population size grows, showing the complexity behind population issues.

Lowering greenhouse gas emissions per economic output or per capita are reasonable targets and inevitably necessary for mitigation of climate change. In principle, a high absolute value for greenhouse gas intensity may depict more inefficient consumption or a more energy intensive structure of economy together with an emission intensive energy production structure. The potential and costs of reducing greenhouse gas intensity may vary extensively between the Member States due to several causes, such as structure of economy, energy production mix, natural resources, climatic and geographical conditions, population density, and public consumption which are not considered in the approaches based on a few macro-figures. Consideration of national features would be important in particular for countries that vary significantly from the average.

Finally, the use of particular macro-figures does not objectively consider consumption. Majority of emission inventories allocate emissions to countries based on their production. However, there are significant amounts of emissions embodied in traded goods. According to (Peters \& Hertwich 2008) most countries in the EU27 were net importers of embodied GHG emissions in traded goods (Fig. 5). Only the Czech Republic, Romania, Bulgaria, Poland and Finland were net exporters, i.e. production-based emissions were larger than consumption-based. If consumption based emissions were considered in effort sharing these countries' reduction targets would most likely be lowered. The EU27 as a whole is a net importer; production based emissions covered 89\% of the consumption in 2001.

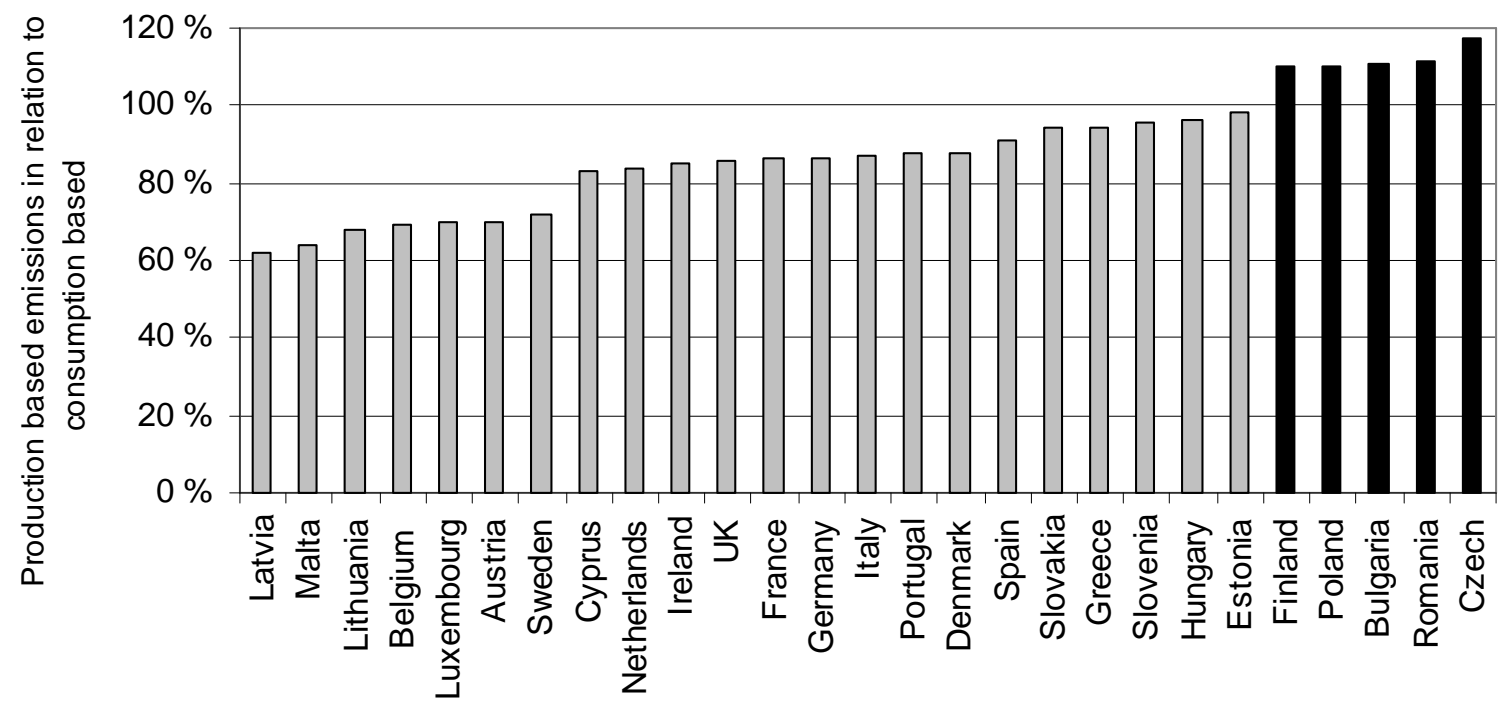

Figure 5. Production based GHG emissions (\%) in relation to consumption based emissions in 2001 estimated by Peters \& Hertwich (2008). Countries with over 100\% share (dark colums) 
are net exporters of embodied emissions in traded goods; others are net importers (grey columns).

\subsection{Concluding remarks}

The effort all EU members is needed in order to achieve GHG emission reductions of $20 \%$ within the European Union by 2020. The required country-specific reductions in the sectors outside emission trade such as transportation, housing, services and agriculture will depend on the applied principle of effort sharing, the allocation of reductions between ETS and nonETS sectors, the selected base year, and forecasts used. Macro-figures of economy, emissions and population are useful when exploring the trends and targets of future emissions. However, when the aim is to understand the causes for the emissions and reach greater dimensions of equity in effort sharing, a more detailed consideration of the national circumstances may be required to achieve a fair solution. We recommend that different types of indicators and models are used, and assumptions are carefully considered. This provides adequate perspective for the proposed emission reductions. Also, when using forecasts or projections in effort sharing, developing methods that use some kind of rules that allow for adjustment after the primary targets have been set could be valuable for mitigating the impacts of unsuccessful forecasts. Finally, any analysis like this provides relevant information for policy making, but political will, negotiations skills, and the practical capacity of implementing the reductions will eventually determine the success in lowering the GHG emissions as desired.

\section{Acknowledgements}

This study was conducted in conjunction with the IFEE (Indicators For Eco-Efficiency, grant 117822) project, which was funded by the Academy of Finland. Funding was also attained from the Finnish Ministry of the Environment. We are grateful to Jaakko Ojala, Magnus Cederlöf, Pekka Kauppi, Ilkka Savolainen and Aapo Rautianen, and two anonymous reviewers for their comments on this paper. 
Appendix 1. Total emissions, ETS and non-ETS emissions in EU27 countries 1990 and 2005. In 2020 emissions in the EU27 should be reduced to around $4500 \mathrm{Mt}$.

\begin{tabular}{|c|c|c|c|c|c|c|c|c|c|c|}
\hline Member State & $\begin{array}{l}\text { Total } 1990 \\
\text { emissions } \\
\text { (Mt) }\end{array}$ & $\begin{array}{l}\text { ETS } 1990 \\
\text { (Mt) }\end{array}$ & $\begin{array}{l}\text { Non-ETS } \\
1990 \text { (Mt) }\end{array}$ & $\begin{array}{l}\text { Total } 2005 \\
\text { emissions } \\
\text { (Mt) }\end{array}$ & $\begin{array}{l}\text { ETS } 2005 \\
\text { (Mt) }\end{array}$ & $\begin{array}{l}\text { Non-ETS } \\
2005 \text { (Mt) }\end{array}$ & $\begin{array}{l}2008-2012 \\
\text { ETS Cap } \\
\text { allowed } \\
\text { (Mt) }\end{array}$ & $\begin{array}{l}\text { Change in } \\
\text { total } \\
\text { emissions } \\
1990-2005\end{array}$ & $\begin{array}{l}\text { Change } \\
\text { ETS 1990- } \\
2005\end{array}$ & $\begin{array}{l}\text { Change } \\
\text { Non-ETS } \\
1990-2005\end{array}$ \\
\hline Austria & 79.1 & 37.6 & 41.5 & 93.3 & 33.6 & 59.7 & 30.7 & $18 \%$ & $-11 \%$ & $44 \%$ \\
\hline Belgium & 145.8 & 79.8 & 66.0 & 143.8 & 54.6 & 89.2 & 58.5 & $-1 \%$ & $-32 \%$ & $35 \%$ \\
\hline Bulgaria & 116.1 & 71.2 & 45.0 & 69.8 & 40.5 & 29.3 & 42.3 & $-40 \%$ & $-43 \%$ & $-35 \%$ \\
\hline Cyprus & 6 & 3.4 & 2.6 & 9.9 & 5.0 & 4.9 & 5.5 & $64 \%$ & $48 \%$ & $86 \%$ \\
\hline Czech Republic & 196.2 & 125.6 & 70.6 & 145.6 & 83.0 & 62.6 & 86.8 & $-26 \%$ & $-34 \%$ & $-11 \%$ \\
\hline Denmark & 69 & 34.0 & 35.0 & 63.9 & 26.2 & 37.7 & 24.5 & $-7 \%$ & $-23 \%$ & $8 \%$ \\
\hline Estonia & 43.6 & 33.5 & 10.1 & 20.7 & 12.6 & 8.1 & 12.7 & $-53 \%$ & $-62 \%$ & $-20 \%$ \\
\hline Finland & 71.2 & 37.7 & 33.4 & 69.3 & 33.3 & 36.0 & 37.6 & $-3 \%$ & $-12 \%$ & $8 \%$ \\
\hline France & 564.2 & 208.2 & 356.0 & 553.4 & 132.8 & 420.6 & 132.8 & $-2 \%$ & $-36 \%$ & $18 \%$ \\
\hline Germany & 1227.9 & 695.9 & 531.9 & 1001.5 & 470.7 & 530.8 & 453.1 & $-18 \%$ & $-32 \%$ & $0 \%$ \\
\hline Greece & 108.7 & 64.7 & 44.0 & 139.2 & 71.0 & 68.2 & 69.1 & $28 \%$ & $10 \%$ & $55 \%$ \\
\hline Hungary & 98.7 & 47.3 & 51.4 & 80.5 & 25.8 & 54.7 & 26.9 & $-18 \%$ & $-46 \%$ & $6 \%$ \\
\hline Ireland & 55.4 & 18.8 & 36.5 & 69.9 & 22.4 & 47.5 & 22.3 & $26 \%$ & $19 \%$ & $30 \%$ \\
\hline Italy & 519.5 & 263.3 & 256.1 & 582.2 & 227.1 & 355.1 & 195.7 & $12 \%$ & $-14 \%$ & $39 \%$ \\
\hline Latvia & 26.4 & 10.7 & 15.8 & 10.9 & 2.8 & 8.1 & 3.4 & $-59 \%$ & $-73 \%$ & $-49 \%$ \\
\hline Lithuania & 48.1 & 24.0 & 24.1 & 22.6 & 6.6 & 16.0 & 8.9 & $-53 \%$ & $-73 \%$ & $-33 \%$ \\
\hline Luxembourg & 12.7 & 8.1 & 4.5 & 12.7 & 2.5 & 10.2 & 2.5 & $0 \%$ & $-69 \%$ & $124 \%$ \\
\hline Malta & 2.2 & 1.5 & 0.8 & 3.4 & 2.0 & 1.4 & 2.1 & $55 \%$ & $35 \%$ & $88 \%$ \\
\hline Netherlands & 213 & 109.5 & 103.5 & 212.1 & 80.6 & 131.5 & 85.8 & $0 \%$ & $-26 \%$ & $27 \%$ \\
\hline Poland & 486.2 & 313.4 & 172.9 & 399 & 203.5 & 195.5 & 208.5 & $-18 \%$ & $-35 \%$ & $13 \%$ \\
\hline Portugal & 59.9 & 29.9 & 30.0 & 85.5 & 36.8 & 48.7 & 34.8 & $43 \%$ & $23 \%$ & $62 \%$ \\
\hline Romania & 248.7 & 159.8 & 88.9 & 153.7 & 70.7 & 83.0 & 75.9 & $-38 \%$ & $-56 \%$ & $-7 \%$ \\
\hline Slovakia & 73 & 44.4 & 28.6 & 48.7 & 25.3 & 23.4 & 30.9 & $-33 \%$ & $-43 \%$ & $-18 \%$ \\
\hline Slovenia & 18.4 & 10.7 & 7.7 & 20.3 & 8.7 & 11.6 & 8.3 & $10 \%$ & $-18 \%$ & $50 \%$ \\
\hline Spain & 287.4 & 150.1 & 137.3 & 440.6 & 185.1 & 255.5 & 152.3 & $53 \%$ & $23 \%$ & $86 \%$ \\
\hline Sweden & 72.2 & 27.9 & 44.3 & 67 & 19.4 & 47.6 & 22.8 & $-7 \%$ & $-30 \%$ & $7 \%$ \\
\hline United Kingdom & 771.4 & 393.5 & 377.9 & 657.4 & 243.2 & 414.2 & 246.2 & $-15 \%$ & $-38 \%$ & $10 \%$ \\
\hline $\begin{array}{l}\text { EU-27 } \\
\text { Sources: EC (2007b) fo }\end{array}$ & $\begin{array}{r}5620.9 \\
\text { missions in }\end{array}$ & $\begin{array}{l}3004.4 \\
\end{array}$ & $\begin{array}{l}2616.6 \\
7) \text { for }\end{array}$ & $\begin{array}{l}5177 \\
\text { ors' emiss }\end{array}$ & $\begin{array}{r}2122.6 \\
2005 . E C\end{array}$ & $\begin{array}{c}3054.4 \\
\text { for ETS car }\end{array}$ & 2081.0 & $\begin{array}{l}-8 \% \\
\text { rostat (2 }\end{array}$ & $\begin{array}{l}-29 \% \\
\text { hares of }\end{array}$ & $\begin{array}{l}17 \% \\
\text { nn-ETS }\end{array}$ \\
\hline
\end{tabular}

ETS emissions are estimated based on emission from Energy industries, manufacturing industries and construction, and industrial processes. 
Appendix 2. Population and non-ETS GDP in the EU27 countries, projections for 2008 and 2020 and annual change during 13 years.

\begin{tabular}{|c|c|c|c|c|c|c|}
\hline Country & $\begin{array}{l}\text { Population } \\
\text { Eurostat } \\
2008\end{array}$ & $\begin{array}{l}\text { Population } \\
2020 \\
\text { Eurostat } \\
\text { baseline }\end{array}$ & $\begin{array}{l}\text { Annual } \\
\text { Population } \\
\text { growth } \\
2008-2020\end{array}$ & $\begin{array}{l}\text { GDP } 2008 \\
\text { M€ } \\
\text { Eurostat }\end{array}$ & $\begin{array}{l}\text { GDP } 2020 \\
\text { M€ } \\
\text { Saikku et al. } \\
2008\end{array}$ & $\begin{array}{l}\text { Annual } \\
\text { GDP growth } \\
2008-2020\end{array}$ \\
\hline Austria & 8211791 & 8441093 & $0,2 \%$ & 171642 & 220169 & $1,9 \%$ \\
\hline Belgium & 10504062 & 10790021 & $0,2 \%$ & 197405 & 252128 & $1,9 \%$ \\
\hline Bulgaria & 7556914 & 6796052 & $-0,8 \%$ & 55291 & 122684 & $6,3 \%$ \\
\hline Cyprus & 765715 & 865593 & $0,9 \%$ & 12329 & 19843 & $3,7 \%$ \\
\hline Czech Republic & 10154126 & 9901848 & $-0,2 \%$ & 106271 & 183427 & $4,3 \%$ \\
\hline Denmark & 5446731 & 5526033 & $0,1 \%$ & 130611 & 167407 & $1,9 \%$ \\
\hline Estonia & 1327583 & 1247772 & $-0,5 \%$ & 18493 & 28832 & $3,5 \%$ \\
\hline Finland & 5269928 & 5404735 & $0,2 \%$ & 92000 & 120333 & $2,1 \%$ \\
\hline France & 60985655 & 63571292 & $0,3 \%$ & 1234587 & 1571287 & $1,9 \%$ \\
\hline Germany & 82753104 & 82676460 & $0,0 \%$ & 1450534 & 1838186 & $1,8 \%$ \\
\hline Greece & 11199921 & 11427043 & $0,2 \%$ & 166967 & 300242 & $4,6 \%$ \\
\hline Hungary & 10028757 & 9693282 & $-0,3 \%$ & 90401 & 181062 & $5,5 \%$ \\
\hline Ireland & 4225110 & 4756111 & $0,9 \%$ & 111741 & 150108 & $2,3 \%$ \\
\hline Italy & 58532743 & 58299672 & $0,0 \%$ & 935678 & 1359070 & $2,9 \%$ \\
\hline Latvia & 2264794 & 2115426 & $-0,5 \%$ & 30228 & 52629 & $4,4 \%$ \\
\hline Lithuania & 3378964 & 3182215 & $-0,5 \%$ & 35067 & 64785 & $4,8 \%$ \\
\hline Luxembourg & 468947 & 520856 & $0,8 \%$ & 24077 & 32183 & $2,3 \%$ \\
\hline Malta & 415421 & 454020 & $0,7 \%$ & 5460 & 10348 & $5,0 \%$ \\
\hline Netherlands & 16541622 & 17209471 & $0,3 \%$ & 345072 & 440732 & $1,9 \%$ \\
\hline Poland & 37957353 & 37065252 & $-0,2 \%$ & 289189 & 667448 & $6,6 \%$ \\
\hline Portugal & 10637617 & 10770761 & $0,1 \%$ & 135369 & 250573 & $4,9 \%$ \\
\hline Romania & 21477014 & 20342159 & $-0,4 \%$ & 112641 & 325876 & $8,5 \%$ \\
\hline Slovakia & 5359431 & 5270634 & $-0,1 \%$ & 42989 & 84210 & $5,3 \%$ \\
\hline Slovenia & 2008929 & 2016690 & $0,0 \%$ & 29740 & 43291 & $2,9 \%$ \\
\hline Spain & 44202506 & 45558613 & $0,2 \%$ & 682130 & 1070806 & $3,5 \%$ \\
\hline Sweden & 9116814 & 9575482 & $0,4 \%$ & 183640 & 240567 & $2,1 \%$ \\
\hline United Kingdom & 60517217 & 62929865 & $0,3 \%$ & 1383512 & 1777438 & $1,9 \%$ \\
\hline
\end{tabular}

Sources: Eurostat Database (2008), Saikku et al. (2008) 
Appendix 3. Non-ETS sector emission reduction targets for 2020 compared to non-ETS emissions in 2005.

\begin{tabular}{|c|c|c|c|c|c|c|}
\hline \multirow[t]{2}{*}{ Principle } & \multirow[t]{2}{*}{$\begin{array}{l}\text { GDP/capita } \\
\text { EU Proposal }\end{array}$} & \multirow[t]{2}{*}{$\begin{array}{l}\text { Equal annual } \\
\text { reduction in } \\
\text { non-ETS } \\
\text { GHG per } \\
\text { GDP } \\
\quad \text { SCE1 } \\
\end{array}$} & \multirow[t]{2}{*}{$\begin{array}{l}\text { Equal non- } \\
\text { ETS GHG per } \\
\text { GDP in } 2020 \\
\text { SCE2 }\end{array}$} & \multirow[t]{2}{*}{$\begin{array}{l}\text { Historical } \\
\text { non-ETS } \\
\text { GHG per } \\
\text { GDP } \\
\quad \text { SCE3 } \\
\end{array}$} & \multirow[t]{2}{*}{$\begin{array}{l}\text { Equal non- } \\
\text { ETS GHG per } \\
\text { Capita } \\
\quad \text { SCE4 }\end{array}$} & \multirow[t]{2}{*}{$\begin{array}{l}\text { Average } \\
\text { SCE 1-4 } \\
\\
\text { Average } \\
\end{array}$} \\
\hline & & & & & & \\
\hline AUSTRIA & $-16 \%$ & $-21 \%$ & $-11 \%$ & $-5 \%$ & $-20 \%$ & $-14 \%$ \\
\hline BELGIUM & $-15 \%$ & $-22 \%$ & $-32 \%$ & $-15 \%$ & $-32 \%$ & $-25 \%$ \\
\hline BULGARIA & $20 \%$ & $36 \%$ & $1 \%$ & $21 \%$ & $31 \%$ & $22 \%$ \\
\hline CYPRUS & $-5 \%$ & $-1 \%$ & $-1 \%$ & $-4 \%$ & $1 \%$ & $-1 \%$ \\
\hline CZECHR. & $9 \%$ & $6 \%$ & $-29 \%$ & $10 \%$ & $-11 \%$ & $-6 \%$ \\
\hline DENMARK & $-20 \%$ & $-22 \%$ & $7 \%$ & $-34 \%$ & $-17 \%$ & $-16 \%$ \\
\hline ESTONIA & $11 \%$ & $-5 \%$ & $-14 \%$ & $-12 \%$ & $-13 \%$ & $-11 \%$ \\
\hline FINLAND & $-16 \%$ & $-20 \%$ & $-19 \%$ & $-36 \%$ & $-16 \%$ & $-23 \%$ \\
\hline FRANCE & $-14 \%$ & $-22 \%$ & $-10 \%$ & $-25 \%$ & $-15 \%$ & $-18 \%$ \\
\hline GERMANY & $-14 \%$ & $-22 \%$ & $-16 \%$ & $-26 \%$ & $-12 \%$ & $-19 \%$ \\
\hline GREECE & $-4 \%$ & $10 \%$ & $6 \%$ & $25 \%$ & $-6 \%$ & $9 \%$ \\
\hline HUNGARY & $10 \%$ & $23 \%$ & $-20 \%$ & $26 \%$ & $0 \%$ & $7 \%$ \\
\hline IRELAND & $-20 \%$ & $-18 \%$ & $-24 \%$ & $-55 \%$ & $-44 \%$ & $-35 \%$ \\
\hline ITALY & $-13 \%$ & $-11 \%$ & $-8 \%$ & $10 \%$ & $-8 \%$ & $-4 \%$ \\
\hline LATVIA & $17 \%$ & $7 \%$ & $58 \%$ & $-47 \%$ & $48 \%$ & $16 \%$ \\
\hline LITHUANIA & $15 \%$ & $13 \%$ & $-2 \%$ & $-9 \%$ & $12 \%$ & $3 \%$ \\
\hline LUXEMBOURG & $-20 \%$ & $-18 \%$ & $-23 \%$ & $-6 \%$ & $-71 \%$ & $-30 \%$ \\
\hline MALTA & $5 \%$ & $16 \%$ & $75 \%$ & $41 \%$ & $79 \%$ & $53 \%$ \\
\hline NETHERLANDS & $-16 \%$ & $-22 \%$ & $-19 \%$ & $-23 \%$ & $-26 \%$ & $-23 \%$ \\
\hline POLAND & $14 \%$ & $41 \%$ & $-18 \%$ & $4 \%$ & $7 \%$ & $9 \%$ \\
\hline PORTUGAL & $1 \%$ & $13 \%$ & $24 \%$ & $44 \%$ & $24 \%$ & $27 \%$ \\
\hline ROMANIA & $19 \%$ & $77 \%$ & $-5 \%$ & $71 \%$ & $38 \%$ & $45 \%$ \\
\hline SLOVAKIA & $13 \%$ & $20 \%$ & $-13 \%$ & $70 \%$ & $27 \%$ & $26 \%$ \\
\hline SLOVENIA & $4 \%$ & $-11 \%$ & $-10 \%$ & $-15 \%$ & $-2 \%$ & $-9 \%$ \\
\hline SPAIN & $-10 \%$ & $-4 \%$ & $1 \%$ & $29 \%$ & $0 \%$ & $7 \%$ \\
\hline SWEDEN & $-17 \%$ & $-20 \%$ & $22 \%$ & $-33 \%$ & $13 \%$ & $-4 \%$ \\
\hline UK & $-16 \%$ & $-21 \%$ & $4 \%$ & $-35 \%$ & $-14 \%$ & $-17 \%$ \\
\hline
\end{tabular}


Appendix 4. Difference in terms of percentage points in test runs compared to the base case. In the test runs, the implications of changing base year for emissions (test run 1), varying ETS allocations (test runs $2 \& 3$ ) and changing GDP forecasts (test run 4), changing GDP assumptions (test run 5) and changing population forecasts (test run 6) were studied. Test runs that lead to 2 percentage point difference or less for all countries, are left out from the table (scenarios 2 and 4 in test run 1, test runs 2 and 5 as a whole, scenarios 1-3 in test runs 6 a and $6 b)$.

\begin{tabular}{|c|c|c|c|c|c|c|c|c|c|c|c|c|c|c|}
\hline \multirow[b]{2}{*}{ Scenario } & \multicolumn{2}{|c|}{ Test run 1} & \multicolumn{4}{|l|}{ Test run 3} & \multicolumn{3}{|c|}{ Test run $4 \mathrm{a}$} & \multicolumn{3}{|c|}{ Test run $4 \mathrm{~b}$} & \multirow{2}{*}{$\begin{array}{l}\text { Test run } \\
6 \mathrm{a} \\
4 \\
\end{array}$} & \multirow{2}{*}{\begin{tabular}{|l|}
$\begin{array}{l}\text { Test run } \\
6 \mathrm{~b}\end{array}$ \\
4 \\
\end{tabular}} \\
\hline & 1 & 3 & 1 & 2 & 3 & 4 & 1 & 2 & 3 & 1 & 2 & 3 & & \\
\hline AUSTRIA & $4 \%$ & $4 \%$ & $-12 \%$ & $-14 \%$ & $-14 \%$ & $-12 \%$ & $4 \%$ & $8 \%$ & $5 \%$ & $-10 \%$ & $8 \%$ & $-12 \%$ & $0 \%$ & $0 \%$ \\
\hline BELGIUM & $3 \%$ & $3 \%$ & $-12 \%$ & $-10 \%$ & $-13 \%$ & $-10 \%$ & $8 \%$ & $10 \%$ & $9 \%$ & $-8 \%$ & $9 \%$ & $-8 \%$ & $0 \%$ & $1 \%$ \\
\hline BULGARIA & $5 \%$ & $4 \%$ & $-21 \%$ & $-15 \%$ & $-19 \%$ & $-20 \%$ & $-110 \%$ & $-81 \%$ & $-97 \%$ & $-70 \%$ & $-40 \%$ & $-62 \%$ & $1 \%$ & $-1 \%$ \\
\hline CYPRUS & $-5 \%$ & $-6 \%$ & $-15 \%$ & $-15 \%$ & $-15 \%$ & $-15 \%$ & $-16 \%$ & $-14 \%$ & $-16 \%$ & $-14 \%$ & $7 \%$ & $-14 \%$ & $5 \%$ & $-5 \%$ \\
\hline CZECHR. & $3 \%$ & $2 \%$ & $-16 \%$ & $-11 \%$ & $-17 \%$ & $-14 \%$ & $-60 \%$ & $-39 \%$ & $-63 \%$ & $-35 \%$ & $-12 \%$ & $-36 \%$ & $1 \%$ & $0 \%$ \\
\hline DENMARK & $2 \%$ & $2 \%$ & $-12 \%$ & $-16 \%$ & $-10 \%$ & $-13 \%$ & $19 \%$ & $31 \%$ & $16 \%$ & $-5 \%$ & $18 \%$ & $-4 \%$ & $-1 \%$ & $0 \%$ \\
\hline ESTONIA & $-25 \%$ & $-23 \%$ & $-15 \%$ & $-13 \%$ & $-14 \%$ & $-13 \%$ & $-66 \%$ & $-59 \%$ & $-61 \%$ & $-35 \%$ & $-18 \%$ & $-32 \%$ & $3 \%$ & $-3 \%$ \\
\hline FINLAND & $5 \%$ & $3 \%$ & $-12 \%$ & $-12 \%$ & $-10 \%$ & $-13 \%$ & $10 \%$ & $13 \%$ & $8 \%$ & $-6 \%$ & $13 \%$ & $-4 \%$ & $-1 \%$ & $1 \%$ \\
\hline FRANCE & $3 \%$ & $2 \%$ & $-12 \%$ & $-14 \%$ & $-11 \%$ & $-13 \%$ & $8 \%$ & $13 \%$ & $8 \%$ & $-9 \%$ & $9 \%$ & $-9 \%$ & $-1 \%$ & $1 \%$ \\
\hline GERMANY & $6 \%$ & $5 \%$ & $-12 \%$ & $-13 \%$ & $-11 \%$ & $-13 \%$ & $21 \%$ & $26 \%$ & $20 \%$ & $-7 \%$ & $11 \%$ & $-7 \%$ & $0 \%$ & $-1 \%$ \\
\hline GREECE & $5 \%$ & $5 \%$ & $-17 \%$ & $-16 \%$ & $-19 \%$ & $-14 \%$ & $-31 \%$ & $-28 \%$ & $-35 \%$ & $-34 \%$ & $-15 \%$ & $-38 \%$ & $-1 \%$ & $-1 \%$ \\
\hline HUNGARY & $0 \%$ & $-1 \%$ & $-19 \%$ & $-12 \%$ & $-19 \%$ & $-15 \%$ & $-73 \%$ & $-46 \%$ & $-75 \%$ & $-48 \%$ & $-20 \%$ & $-50 \%$ & $1 \%$ & $-1 \%$ \\
\hline IRELAND & $3 \%$ & $2 \%$ & $-13 \%$ & $-12 \%$ & $-7 \%$ & $-9 \%$ & $-10 \%$ & $-7 \%$ & $-5 \%$ & $-8 \%$ & $10 \%$ & $-4 \%$ & $0 \%$ & $0 \%$ \\
\hline ITALY & $-1 \%$ & $-2 \%$ & $-14 \%$ & $-14 \%$ & $-16 \%$ & $-14 \%$ & $4 \%$ & $7 \%$ & $5 \%$ & $-15 \%$ & $4 \%$ & $-18 \%$ & $0 \%$ & $1 \%$ \\
\hline LATVIA & $-3 \%$ & $-1 \%$ & $-16 \%$ & $-24 \%$ & $-8 \%$ & $-22 \%$ & $-79 \%$ & $-116 \%$ & $-39 \%$ & $-62 \%$ & $-76 \%$ & $-31 \%$ & $3 \%$ & $-2 \%$ \\
\hline LITHUANIA & $-11 \%$ & $-9 \%$ & $-17 \%$ & $-15 \%$ & $-14 \%$ & $-17 \%$ & $-75 \%$ & $-64 \%$ & $-60 \%$ & $-55 \%$ & $-35 \%$ & $-44 \%$ & $2 \%$ & $-2 \%$ \\
\hline LUXEMBOURG & $1 \%$ & $1 \%$ & $-12 \%$ & $-12 \%$ & $-14 \%$ & $-4 \%$ & $10 \%$ & $12 \%$ & $12 \%$ & $-5 \%$ & $13 \%$ & $-6 \%$ & $0 \%$ & $-1 \%$ \\
\hline MALTA & $0 \%$ & $-1 \%$ & $-18 \%$ & $-27 \%$ & $-21 \%$ & $-27 \%$ & $-44 \%$ & $-63 \%$ & $-54 \%$ & $-53 \%$ & $-56 \%$ & $-64 \%$ & $7 \%$ & $-6 \%$ \\
\hline NETHERLANDS & $-3 \%$ & $-3 \%$ & $-12 \%$ & $-12 \%$ & $-12 \%$ & $-11 \%$ & $13 \%$ & $17 \%$ & $13 \%$ & $-2 \%$ & $18 \%$ & $-2 \%$ & $0 \%$ & $0 \%$ \\
\hline POLAND & $-14 \%$ & $-11 \%$ & $-21 \%$ & $-13 \%$ & $-16 \%$ & $-16 \%$ & $-75 \%$ & $-43 \%$ & $-55 \%$ & $-62 \%$ & $-25 \%$ & $-46 \%$ & $1 \%$ & $-1 \%$ \\
\hline PORTUGAL & $13 \%$ & $16 \%$ & $-17 \%$ & $-19 \%$ & $-22 \%$ & $-19 \%$ & $-33 \%$ & $-33 \%$ & $-42 \%$ & $-41 \%$ & $-25 \%$ & $-52 \%$ & $0 \%$ & $-1 \%$ \\
\hline ROMANIA & $5 \%$ & $4 \%$ & $-27 \%$ & $-14 \%$ & $-26 \%$ & $-21 \%$ & $-140 \%$ & $-74 \%$ & $-135 \%$ & $-100 \%$ & $-43 \%$ & $-96 \%$ & $0 \%$ & $-1 \%$ \\
\hline SLOVAKIA & $14 \%$ & $19 \%$ & $-18 \%$ & $-13 \%$ & $-25 \%$ & $-19 \%$ & $-72 \%$ & $-51 \%$ & $-102 \%$ & $-40 \%$ & $-15 \%$ & $-56 \%$ & $0 \%$ & $-1 \%$ \\
\hline SLOVENIA & $3 \%$ & $3 \%$ & $-14 \%$ & $-14 \%$ & $-13 \%$ & $-15 \%$ & $-53 \%$ & $-52 \%$ & $-50 \%$ & $-25 \%$ & $-9 \%$ & $-24 \%$ & $4 \%$ & $-3 \%$ \\
\hline SPAIN & $-1 \%$ & $-3 \%$ & $-15 \%$ & $-15 \%$ & $-19 \%$ & $-15 \%$ & $-21 \%$ & $-19 \%$ & $-28 \%$ & $-27 \%$ & $-11 \%$ & $-36 \%$ & $0 \%$ & $0 \%$ \\
\hline SWEDEN & $-1 \%$ & $-1 \%$ & $-12 \%$ & $-19 \%$ & $-10 \%$ & $-17 \%$ & $8 \%$ & $16 \%$ & $7 \%$ & $-18 \%$ & $-4 \%$ & $-15 \%$ & $-1 \%$ & $0 \%$ \\
\hline UK & $-6 \%$ & $-5 \%$ & $-12 \%$ & $-16 \%$ & $-10 \%$ & $-13 \%$ & $10 \%$ & $17 \%$ & $8 \%$ & $-13 \%$ & $4 \%$ & $-11 \%$ & $0 \%$ & $0 \%$ \\
\hline
\end{tabular}




\section{References}

Blok, K., Phylipsen, G.J.M., Bode, J.W., 1997. The triptique approach. Burden differentiation of $\mathrm{CO}_{2}$ emission reduction among European Union member states. Discussion paper for the informal workshop for the European Union Ad Hoc Group on Climate Zeist, The Netherlands, 16-17 January 1997.

Delhotal, K. C., Chesnaye, F. C. de la, Gardiner, A., Bates, J., 2006. M itigation of M ethane and Nitrous Oxide Emissions from Waste, Energy and Industry. The Energy Journal, special issue $3,45-62$.

den Elzen M.G.J., Lucas P.L., Gijsen A., 2007. Exploring European countries' emission reduction targets, abatement costs and measures needed under the 2007 EU reduction objectives. M NP Report 500114009/2007. Netherlands Environmental assessment agency.

Ekholm, T., Lehtilä, A., Savolainen, I. 2008. Unilateral emission reductions of the EU and multilateral emission reductions of the developed countries - Assessing the impact on Finland with TIMES model (in Finnish with English abstract). VTT Working Papers 96. Espoo, Finland, March 2008. 57 p.

European Commission, 2007a. National Allocation Plans: Second Phase (2008-2012) Available at: http://ec.europa.eu/environment/climat/2nd_phase_ep.htm

European Commission, 2007b. Commission staff working document. Accompanying document to the communication from the commission. Progress towards achieving the Kyoto objectives. COM (2007)757 final. SEC(2007) 1576. Brussels, 27.11.2007.

European Commission, 2008. Package of Implementation measures for the EU's objectives on climate change and renewable energy for 2020. Brussels.

Eurostat, 2008. Eurostat database. Available at: ec.europa.eu/ eurostat

Heston, A., Summers, R., Aten, B., 2007. Penn World Table, Version 6.2. Center for International Comparisons of Production, Income and Prices at the University of Pennsylvania. http://pwt.econ.upenn.edu/

Mantzos, L., Capros, P., Kouvaritakis, N., Zeka-Paschou, M., 2003. European Energy and Transport Trends to 2030, EU DG-TREN, Brussels, Belgium.

Martinez-Zarzoso I, Bengochea-Morancho A, Morales-Lage R., 2007. The impact of population on $\mathrm{CO}_{2}$ emissions: evidence from European countries. Environmental \& Resource Economics 38 (4), 497-512.

Meyerson F.A.B., 1998. Population, carbon emissions, and global warming: the forgotten relationship at Kyoto. Popul. Dev. Rev. 24, 115-130. 
Peters, G., Hertwich, E., 2008. $\mathrm{CO}_{2}$ embodied in international trade with implications for global climate policy. Environmental science and technology 42 (5), 1401 - 1407.

Phylipsen, G.J.M., Bode, J.W., Blok, K., Merkus, H., Metz, B., 1998. A Triptych sectoral approach to burden differentiation; GHG emissions in the European bubble. Energy Policy 26 (12), 929-943.

Phylipsen, D., Höhne, N., Janzic, R. 2004. Implementing Triptych 6.0 - Technical report. DM 70046 / ICC03080. Commissioned by RIVM. November 2004. 56 p.

Russ P., Wiesenthal T., van Regemorter D., Ciscar J., 2007. Global Climate Policy Scenarios for 2030 and beyond. Analysis of Greenhouse Gas Emission Reduction Pathway scenarios with the POLES and GEM-E3 models. European Commission Joint Research Centre, Institute for Prospective Technological Studies, Sevilla, Spain.

Saikku, L., Rautiainen A., Kauppi, P.E., 2008. The sustainability challenge of meeting carbon dioxide targets in Europe by 2020. Energy Policy 36 (2), 730-742.

Sijm, J.P.M., Berk, M., den Elzen, M., van den Wijngaart, R., 2007. Options for post-2012 EU burden sharing and EU ETS allocation. Climate change scientific assessment and policy assessment. ECN \& Netherlands Environmental Agency. Netherlands.

Soimakallio, S., Savolainen, I., Syri, S., 2005. GHG emission development in the EU and assessment of the Triptych approach applicability for the EU internal burden sharing. Extended English Summary. VTT project Report no. PRO3/P54/04. 32 p. Helsinki, Finland.

Soimakallio, S., Perrels, A., Honkatukia, J., Moltmann, S., Höhne, N. 2006. Analysis and Evaluation of the Triptych 6 - Case Finland. VTT Working Papers 48, Espoo 2006. http://www.vtt.fi/inf/pdf/w orkingpapers/2006/W 48.pdf

Torvanger, A., Ringius, L., 2001. Burden differentiation: criteria for evaluation and development of burden sharing rules. CICERO Center for International Climate and Environmental Research. Oslo, Norway.

\section{Biographical notes}

Laura Saikku is a Ph.D. student in environmental science and policy at the University of Helsinki. She holds a M aster's degree in agriculture and forestry. Her research interests are in the field of industrial ecology. Her recent research focuses on European climate policy and the challenge of meeting emissions reduction targets, as well as on the nutrient flows of the human economy.

Sampo Soimakallio, Master of Science in Technology, is working as a senior research scientist at the VTT Technical Research Centre of Finland. He has been involved in analysing various principles in the differentiation of emission reduction commitments among countries. He is also working with climatic sustainability of biofuels. 